\title{
Profil Hematologi sebagai Prediktor Sepsis pada Sindrom Syok Dengue
}

\author{
Deddy Hediyanto, Ida Safitri Laksanawati, Ratni Indrawanti, Desy Rusmawaningtyas, Eggi Arguni
}

Bagian Ilmu Kesehatan Anak Fakultas Kedokteran Universitas Gajah Mada/RSUP Dr. Sardjito, Yogyakarta

Latar belakang. Infeksi dengue di daerah endemis dapat terjadi bersamaan dengan infeksi lain. Penelitian tentang infeksi dengue pada anak sudah banyak dilakukan, tetapi masih sedikit yang meneliti tentang kejadian sepsis pada sindrom syok dengue (SSD). Profil hematologi sebagai pemeriksaan yang mudah dilakukan, diharapkan dapat digunakan sebagai prediktor sepsis pada SSD.

Tujuan. Mengetahui profil hematologi sebagai prediktor sepsis pada SSD.

Metode. Penelitian kohort retrospektif pada anak usia 1 bulan-18 tahun yang diambil dari data rekam medis pasien SSD dengan sepsis maupun tidak sepsis dan dirawat di RSUP Dr. Sardjito mulai 1 Januari 2011- 31 Desember 2014. Profil hematologi dan C-reactive protein (CRP) yang digunakan adalah pemeriksaan yang diambil saat pasien pertama kali masuk ke rumah sakit. Analisis statistik dikerjakan dengan analisis univariat, kemaknaan dengan Odds ratio (OR) dan interval kepercayaan 95\% (IK95\%).

Hasil. Didapatkan 98 pasien yang memenuhi kriteria inklusi SSD, di antaranya 30 pasien SSD (30,6\%) menderita sepsis. Tidak ada profil hematologi saat pasien pertama kali masuk rumah sakit menjadi prediktor sepsis pada SSD. Pemeriksaan kadar Hb (rerata $13,98 \pm 2,28 \mathrm{~g} / \mathrm{dL}, \mathrm{p}=0,897$ ), hematokrit saat datang (rerata 40,5 $\pm 6,6 \% ; \mathrm{p}=0,369$ ), leukosit (median 5,68x 1033 sel/ $\mu \mathrm{L} ; \mathrm{p}=0,619$ ), trombosit (median $25,5 \times 10^{3} \mathrm{sel} / \mu \mathrm{L} ; \mathrm{p}=0,841$ ). Pemeriksaan CRP dilakukan pada 40 pasien. Pasien SSD dengan sepsis $57,9 \%$ memiliki kadar CRP $\geq 6$ mg/L signifikan lebih tinggi dibanding SSD tanpa sepsis (23,8\%) dengan nilai p=0,028; OR 2,1 (IK95\%: 1,1-3,9). Pemeriksaan biakan darah dilakukan pada 35 pasien, dengan biakan tumbuh pada 6 pasien DSS yang sepsis.

Kesimpulan. Kadar CRP $\geq 6 \mathrm{mg} / \mathrm{L}$ berhubungan signifikan dengan kejadian sepsis pada SSD, sedangkan profil hematologi lain tidak. Sari Pediatri 2016;18(4):260-4

Keyword: profil hematologi, SSD, sepsis

\section{Hematological Profile as a Predictor for Sepsis in Dengue Shock Syndrome}

Deddy Hediyanto, Ida Safitri Laksanawati, Ratni Indrawanti, Eggi Arguni, Desy Rusmawaningtyas

Background. Dengue infection in endemic area could occur with co-infection. Sepsis in dengue shock syndrome (DSS) is still need to be studied. It is important to understand abnormalities in hematological profile as a predictor for sepsis in DSS.

Objectives. To identify hematological profile as a predictor for sepsis in DSS.

Methods. This retrospective cohort design study investigated medical record of 1 month to 18 years old children diagnosed as DSS with and without sepsis in Dr. Sardjito General Hospital, Yogayakarta from January 1, 2011 to December 31, 2014. Univariat statistical analysis was done with significance presented as odds ratio with $95 \%$ CI.

Result. Of 98 patients diagnosed with DSS included in this study, 30 (30.6\%) patients had sepsis. None of the hematological profile at first time admitted to the hospital played role as predictor for sepsis in DSS. Hemoglobin level (mean $13.98 \pm 2.28 \mathrm{~g} / \mathrm{dL}, \mathrm{p}=0.897)$, hematokrit level (mean 40.5 $\pm 6.6 \% ; \mathrm{p}=0.369)$, leukosit count (median 5.68x 10 $\left.0^{3} \mathrm{cell} / \mu \mathrm{L} ; \mathrm{p}=0.619\right)$ and thrombocyte count (median $\left.25.5 \times 10^{3} \mathrm{cell} / \mu \mathrm{L} ; \mathrm{p}=0841\right)$. CRP test was investigated in 40 patients $(\mathrm{p}=0.064)$. Patients with CRP level $\geq 6 \mathrm{mg} / \mathrm{L}$ have higher risk for sepsis OR 2.1 (95\%CI 1.1-3.9). Blood culture were obtained in 35 patients, positive bacterial growth were indetified in 6 (30\%) patients with sepsis.

Conclusion. Increasing of CRP level have higher risk for sepsis in DSS children, while other hematological profiles were not. Sari Pediatri 2016;18(4):260-4

Keywords: hematological profile, DSS, sepsis

Alamat korespondensi: Dr. Deddy Hediyanto, SpA, Dr. Ida Safitri Laksanawati, SpA. BIKA Fakultas Kedokteran Universitas Gajah Mada/ RSUP Dr. Sardjito, Yogyakarta. Email: drdeddy@yahoo.com 
I nfeksi virus dengue merupakan masalah kesehatan global. Dalam tiga dekade terakhir terjadi peningkatan angka kejadian penyakit di berbagai negara yang dapat menimbulkan kematian sekitar kurang dari 1\%. Diperkirakan setiap tahun sekitar 50 juta manusia terinfeksi virus dengue yang 500.000 di antaranya memerlukan rawat inap, dengan proporsi terbesar $(90 \%)$ adalah anak berusia kurang dari 5 tahun, dan 2,5\% di antaranya meninggal. ${ }^{1}$ Pada tahun 2013, WHO memperkirakan ada 50-100 juta kasus infeksi dengue per tahun, tetapi estimasi lain memperkirakan bahwa infeksi dengue terjadi 390 juta per tahun. ${ }^{2}$

Indonesia merupakan daerah endemis infeksi dengue dengan sebaran di seluruh wilayah tanah air. Puncak kasus terjadi tahun 2010, jumlah pasien demam berdarah dengue (DBD) dilaporkan 156.086 kasus dengan angka kematian 1.358 ( $\mathrm{CFR}=0,87 \%)$. Pada tahun 2013, kasus DBD yang dilaporkan 112511 (incidence rate, IR=45,85 per 100.000 penduduk), dengan jumlah kematian 871 orang (case fatality rate, CFR $=0,77 \%$ ). Pada tahun 2013 di Daerah Istimewa Yogyakarta terdapat 96 kasus per 100.000 penduduk dengan $\mathrm{CFR}=0,48 \%$ Pada tahun 2014, terdapat 99.499 penderita DBD dengan angka kematian 905 $(\mathrm{CFR}=0,91 \%) .^{3}$

Pasien dengan infeksi virus dengue mempunyai imunitas yang buruk selama periode konvalesens yang membuat mudah terkena infeksi lain. ${ }^{4}$ Beberapa pasien infeksi dengue dapat mengalami manifestasi yang tidak lazim berupa ensefalopati-ensefalitis dengue, perdarahan masif, infeksi ganda (dual infection), kelainan ginjal dan miokarditis. Di daerah endemis terdapat laporan infeksi dengue terjadi bersamaan dengan infeksi lain, seperti diare akut, pneumonia, campak, cacar air, demam tifoid, infeksi saluran kemih, leptospirosis, dan malaria. Pravelansi dual infection masih jarang dilaporkan. Sumber infeksi dapat terjadi sebelum masuk rumah sakit atau pada saat rawat inap (health care associated infection), misalnya, trombloflebitis, pneumonia, infeksi saluran kemih dan sepsis. ${ }^{1}$ Bakteremia dengan infeksi dengue jarang terjadi dan dilaporkan. ${ }^{5}$ Syok pada demam berdarah dapat menyebabkan iskemia usus dan menyebabkan translokasi bakteri dari lumen usus ke sirkulasi darah. Endotoksin ini akan mengaktivasi sitokin terutama TNF- $\alpha$ dan IL-1. Penelitian Hadinegoro membuktikan bahwa endotoksemia berhubungan erat dengan syok pada demam berdarah. Endotoksemia terjadi pada $50 \%$ sindrom syok dengue dan $50 \%$ demam berdarah non syok. Beberapa literatur menyebutkan keterlibatan Gram negatif jenis Enterobacteriacaea, dengan hanya satu kasus dilaporkan koinfeksi dengan S. aureus. ${ }^{5}$ Patofisiologi terjadinya dual infection dikarenakan infeksi virus dengue merusak lapisan mukosa usus sehingga sebagai pintu masuk bagi flora normal di usus yang berubah menjadi patogen, dan kemudian invasi ke peredaran darah. ${ }^{6}$

\section{Metode}

Penelitian ini menggunakan rancangan penelitian deskriptif analitik dengan desain kohort retrospektif. Data diambil dari rekam medis pasien SSD dengan sepsis maupun tidak sepsis yang dirawat di RSUP Dr. Sardjito, Yogyakarta; mulai 1 Januari 2011 sampai 31 Desember 2014. Metode pengambilan sampel dilakukan dengan metode consequtive sampling dari rekam medis. Dalam penelitian ini semua pasien SSD dengan sepsis maupun tidak sepsis dari usia 1 bulan hingga 18 tahun dan dirawat di RSUP Dr. Sardjito, diikutsertakan dalam penelitian. Profil hematologi dan $C$-reactive protein (CRP) yang digunakan adalah pemeriksaan yang diambil saat pasien pertama kali masuk ke rumah sakit.

Data dianalis dengan progam SPSS (statistic progam for social science) 16.0 for windows. Analisis data meliputi analisis deskriptif dan uji chi square. Pada analisis deskriptif, data yang berskala kategorikal ditampilkan dalam bentuk distribusi frekuensi dan persentase.

\section{Hasil}

Pada tahun 2011 sampai 2014 terdapat 98 kasus SSD yang dirawat di RSUP Dr. Sardjito. Karakteristik pasien DSS tertera pada Tabel 1. Terdapat 30 subjek (30,6\%) kasus SSD dengan sepsis. Kelompok SSD dengan sepsis ataupun tanpa sepsis yang datang ke RSUP Dr. Sardjito masih dalam keadaan demam 33,3\% dan $27,9 \%$. Pasien SSD dengan sepsis memiliki rerata umur 7,3 $\pm 4,04$ tahun. Jenis kelamin SSD (laki-laki 43,3\%) dengan sepsis dan SSD tanpa sepsis (laki-laki 57,4\%). Rerata lama rawat pasien SSD kurang dari 5 hari lebih banyak pada pasien SSD tanpa sepsis $(77,78 \%)$.

Profil hematologis pasien SSD dengan sepsis tertera pada Tabel 2. Pasien DSS dengan sepsis memiliki kadar 
Tabel 1. Karakteristik dasar penelitian

\begin{tabular}{lcc}
\hline Karakteristik & $\begin{array}{c}\text { SSD sepsis } \\
\mathrm{n}=30\end{array}$ & $\begin{array}{c}\text { SSD tanpa sepsis } \\
\mathrm{n}=68\end{array}$ \\
\hline Usia (rerata \pm SB) & $7,3 \pm 4,04$ & $7,46 \pm 3,16$ \\
Jenis kelamin, n (\%) & & \\
$\quad$ Laki-laki & $13(43,3)$ & $39(57,4)$ \\
Demam saat datang n (\%) & $10(33,3)$ & $19(27,9)$ \\
Lama rawat ( $\leq 5$ hari) & $11(36,67)$ & $49(77,78)$ \\
Kejadian syok hari ke- (median) & 5 & 5 \\
\hline
\end{tabular}

Tabel 2. Profil hematologis sepsis pada SSD

\begin{tabular}{|c|c|c|c|}
\hline Karakteristik & $\begin{array}{c}\begin{array}{c}\text { SSD sepsis } \\
\mathrm{n}=30\end{array}\end{array}$ & $\begin{array}{c}\text { SSD tanpa sepsis } \\
\mathrm{n}=68\end{array}$ & $\mathrm{p}$ \\
\hline Kadar $\mathrm{Hb}($ rerata $\pm \mathrm{SB})$ & $13,98 \pm 2,28 \mathrm{~g} / \mathrm{dL}$ & $14,05 \pm 2,80 \mathrm{~g} / \mathrm{dL}$ & 0,897 \\
\hline HCT saat datang (rerata $\pm S B)$ & $40,5 \pm 6,6 \%$ & $41 \pm 8,1 \%$ & 0,369 \\
\hline Leukositosis/leukopenia & & & 0,339 \\
\hline Ya, n (\%) & $11(36,7)$ & $32(47,1)$ & \\
\hline Tidak, n (\%) & $19(63,3)$ & $36(52,9)$ & \\
\hline Leukositosis & & & 1,0 \\
\hline Ya, n (\%) & $2(6,7)$ & $4(5,9)$ & \\
\hline Tidak, n (\%) & $28(93,3)$ & $64(94,1)$ & \\
\hline Leukopenia & & & 0,170 \\
\hline Ya, n (\%) & $8(26,7)$ & $28(41,2 \%)$ & \\
\hline Tidak, n (\%) & $22(73,3)$ & $40(58,8 \%)$ & \\
\hline Trombosit $<50 \times 10^{3} \mathrm{sel} / \mu \mathrm{L}$ & & & 0,983 \\
\hline Ya, n (\%) & $23(23,5)$ & $52(53,1)$ & \\
\hline Tidak, n (\%) & $7(7,1)$ & $16(16,3)$ & \\
\hline CRP ( $\mathrm{n}=40$, median) & $6(5-34) \mathrm{mg} / \mathrm{L}$ & $5(5-120) \mathrm{mg} / \mathrm{L}$ & 0,064 \\
\hline \multicolumn{4}{|l|}{ Kadar CRP (mg/L) } \\
\hline \multicolumn{4}{|l|}{$\mathrm{CRP} \geq 5$} \\
\hline $\mathrm{CRP}<5$ & & & \\
\hline
\end{tabular}

Tabel 3. Hasil biakan darah

\begin{tabular}{lcc}
\hline Karakteristik & SSD sepsis & SSD tanpa sepsis \\
\hline Hasil biakan $(\%,(\mathrm{n}=35)$ & $6(30)$ & $1(6,7)$ \\
Tumbuh & $14(70)$ & $14(93,3)$ \\
Tidak tumbuh & & \\
\hline
\end{tabular}

rerata $\mathrm{Hb}$ yang serupa dengan pasien SSD tanpa sepsis, yaitu $13,98 \pm 2,28 \mathrm{~g} / \mathrm{dL}$ dibanding $14,05 \pm 2,80 \mathrm{~g} / \mathrm{dL}$ $(\mathrm{p}=0,897)$. Jumlah leukosit tidak berbeda bermakna antara kedua kelompok dengan nilai median 5,68 $(2,15-20,55) \times 10^{3} \mathrm{sel} / \mu \mathrm{L}$ pada SSD dengan sepsis dan $5,32(1,78-19,69) \times 10^{3} \mathrm{sel} / \mu \mathrm{L}$ pada SSD tanpa sepsis. Pada SSD dengan sepsis, leukositosis maupun leukopenia terjadi pada $36,7 \%$ pasien, tidak berbeda bermakna dengan SSD tanpa sepsis $(47,1 \%)$. Jika leukositosis dan leukopenia dianalisis terpisah, juga tidak ada perbedaan bermakna antara kedua kelompok, dengan nilai $\mathrm{p}=1,0$ pada leukositosis dan $\mathrm{p}=0,170$ pada leukopenia. Trombositopenia pada SSD dengan sepsis tidak berbeda bermakna dengan SSD tanpa 
sepsis ( $\mathrm{p}=0,841)$. Median jumlah trombosit pada SSD dengan sepsis $25,5(9-153) \times 10^{3} \mathrm{sel} / \mu \mathrm{L}$ dibandingkan $29,5(2-195) \times 10^{3} \mathrm{sel} / \mu \mathrm{L}$ pada SSD tanpa sepsis.

Terdapat 40 subjek yang diperiksa CRP, cut off point median nilai CRP digunakan untuk membagi subjek menjadi 2 kelompok yaitu $\geq 6$ dan $<6$. Pasien SSD dengan sepsis 57,9\% memiliki kadar CRP $\geq 6$ $\mathrm{mg} / \mathrm{L}$ signifikan lebih tinggi dibanding SSD tanpa sepsis $(23,8 \%)$ dengan nilai $\mathrm{p}=0,028$ (RR 2, 1; IK95\%: $1,1-3,9)$.

Tigapuluh lima subjek diperiksa biakan darah, 6 (30\%) biakan tumbuh pada pasien SSD dengan sepsis, sedangkan pada SSD tidak sepsis hanya 6,7\%. Kuman yang tumbuh 3/7 adalah Pseudomonas aeruginosa, 1/7 Klebsiella pneumonia, 2/7 Staphylococcus aureus, dan 1/7 Escherichia hermanii.

\section{Pembahasan}

Angka kejadian sepsis pada SSD 30,6\% kasus dari tahun 2011- 2014 yang dirawat di RSUP Dr. Sardjito. Lee melaporkan angka kejadian bakteremia pada pasien dewasa yang menderita DBD 5,5\% di Taiwan. ${ }^{6}$ Pasien SSD datang ke RSUP Dr. Sardjito saat syok dengan median hari demam hari ke-5. Terdapat 33,3\% pasien SSD dengan sepsis dan 27,9\% tidak sepsis yang masih mengalami demam pada saat datang. See $\mathrm{dkk}^{7}$ melaporkan dalam penelitiannya bahwa suhu tidak dapat dipercaya sebagai tanda infeksi bakteri pada pasien dengan infeksi dengue. Pasien SSD dengan sepsis memiliki rerata umur $(7,3 \pm 4,04)$ tahun. Perbandingan karakteristik jenis kelamin antara pasien SSD (laki-laki 43,3\%) dengan sepsis dan SSD tanpa sepsis (laki-laki 57,4\%). Dari penelitian kami, rerata lama rawat pasien SSD yang kurang dari 5 hari lebih banyak pada pasien SSD tanpa sepsis $(77,78 \%)$.

Pasien SSD dengan sepsis memiliki kadar rerata $\mathrm{Hb}$ yang serupa dengan pasien SSD tanpa sepsis, yaitu $13,98 \pm 2,28$ dibanding $14,05 \pm 2,80 \mathrm{~g} / \mathrm{dL}$. Pada SSD dengan sepsis, leukositosis maupun leukopenia terjadi pada $36,7 \%$ pasien, tidak berbeda dengan SSD tanpa sepsis $(47,1 \%)$. Jika leukositosis dan leukopenia dianalisis terpisah, juga tidak terdapat perbedaan antara kedua kelompok, $(\mathrm{p}=1,0$ pada leukositosis dan $\mathrm{p}=0,170$ pada leukopenia). Hal serupa dilaporkan juga oleh Lee $^{6}$ bahwa tidak ada hubungan peningkatan leukosit secara signifikan pada pasien DBD yang mengalami bakteremia. Premaratna ${ }^{8}$ di Srilangka juga melaporkan dalam penelitiannya bahwa angka leukosit tidak dapat membantu untuk mendeteksi bakteremia pada pasien infeksi dengue. Pada penelitian kami, trombositopeni $<50 \times 10^{3} \mathrm{sel} / \mu \mathrm{L}$ pada SSD dengan sepsis $23,5 \%$, sedangkan pada SSD tidak sepsis $53,1 \%$, tetapi tidak bermakna secara statistik $(p=0,983)$. Hal ini sejalan dengan penelitian See $\mathrm{dkk}^{7}$ yang melaporkan bahwa hubungan trombositopeni pada pasien dengue dengan koinfeksi bakteri kurang jelas karena angka trombosit pada dengue memang turun secara progresif sampai hari sakit ke- 5 dan 6.

Pemeriksaan CRP merupakan salah satu marker diagnosis infeksi atau non infeksi, tetapi CRP juga bisa meningkat pada keadaan inlamasi. Dalam penelitian ini, pasien SSD dengan kadar CRP $\geq 6$ $\mathrm{mg} / \mathrm{L}$ berpeluang lebih tinggi mengalami sepsis. Penelitian Premaratna ${ }^{8}$ di Srilanka melaporkan pemeriksaan CRP lebih dapat digunakan untuk mendiagnosis bakteremia dibandingkan hitung jenis leukosit. Sebaliknya, Iskandar ${ }^{9}$ di Jakarta mendapatkan pemeriksaan prokalsitonin, CRP, serta hitung leukosit tidak dapat digunakan untuk memprediksi adanya infeksi bakterial pasien SSD yang dirawat di PICU. Juffrie $\mathrm{dkk}^{10}$ menyebutkan dalam penelitiannya bahwa kadar CRP pada infeksi virus dengue meningkat jika dibandingkan dengan anak sehat, tetapi tidak menunjukkan hubungannya dengan kejadian sepsis pada SSD.

Tigapuluh lima subjek diperiksa biakan darah, sebagian besar adalah Gram negatif dan hanya satu yang Gram positif, yaitu $S$. aureus. Hal tersebut sama dengan penelitian See $\mathrm{dkk}^{7}$ di Singapura yang melaporkan bahwa mayoritas bakteri yang diisolasi dari penderita infeksi dengue adalah bakteri Gram negatif. Hal ini mungkin terjadi akibat invasi bakteri saluran intestinal ke aliran darah karena barier mukosa usus terganggu pada infeksi dengue berat. Dalam penelitiannya, Lee ${ }^{6}$ di Taiwan melaporkan bahwa bakteri utama yang diisolasi dari darah adalah $K$. pneumoni, $M$. lacunata dan E. faecalis. Pada keadaan normal, bakteri tersebut ditemukan dalam saluran intestinal. Penelitian Nagassar ${ }^{11}$ di Jamaika melaporkan bahwa luaran yang buruk pada pasien dengue dengan koinfeksi $S$. aureus bukan suatu ko-insidens dan kemungkinan dapat menyebabkan severe dengue. Araujo $\mathrm{dkk}^{12}$ melaporkan bahwa infeksi $S$. aureus yang terjadi pada pasien dengue hampir sebagian besar karena peningkatan kerentanan imunitas yang disebabkan oleh virus dengue. 


\section{Kesimpulan}

Profil hematologis saat pasien masuk ke rumah sakit seperti hemoglobin, hematokrit, leukositosis, leukopenia, trombositopenia, dan biakan tidak berhubungan dengan kejadian sepsis pada SSD. Kadar $\mathrm{CRP} \geq 6 \mathrm{mg} / \mathrm{L}$ berhubungan signifikan dengan kejadian sepsis pada SSD.

\section{Daftar pustaka}

1. World Health Organization. 2011. Comprehensive Guidelines for Prevention and Control of Dengue and Dengue Haemorrhagic fever, Revised and Expanded Edition. WHO; 2011.

2. Bhatt S, Gething PW, Brady OJ. The global distribution and burden of dengue. Nature 2013; 496:504-7.

3. Ditjen PP\&PL Kementerian Kesehatan Republik Indonesia. Profil Kesehatan Indonesia tahun 2013. Kementerian Kesehatan Republik Indonesia; 2014.

4. Suresh V, Krishna V, Raju CHN, Surya P, Teja VU. A rare case of triple infection with dengue, malaria and typhoid-A case report. Int J Res Dev Health 2013;1:200-3.

5. UKK Infeksi dan Pediatri Tropis IDAI. Pedoman diagnosis dan tata laksana infeksi virus dengue pada anak. UKK Infeksi dan Penyakit Tropis Ikatan Dokter Anak Indonesia, 2014.
6. Lee IK, Liu JW, Yang KD. Clinical characteristic and risk factors for concurrent bacteremia in adult with dengue hemorrhagic fever. Am J Trop Med Hyg 2005;72:221-6.

7. See KC, Phua J, Yip HS, Yeo LL, Lim TK. Identification of concurrent bacterial infection in adult patients with dengue. Am J Trop Med Hyg 2013;89:804-10.

8. Premaratna R, Dissayake D, Silva FHDS, Dassanayake M, Silva HJ. Secondary bacteremia in adult patients with prolonged dengue fever. Ceylon J Med 2015;60:10-2.

9. Iskandar HR, Pudjiadi A, Mulyo D, Pratiwi A, Suryatin Y. Sensitifitas dan spesifitas pemeriksaan procalsitonin, c-reactive protein, dan hitung leukosit umtuk memprediksi infeksi bakterial pada sindrom syok dengue di pediatric intensive care unit. Sari Pediatri 2010;12:233-40.

10. Juffrie M, Meer GM, Hack CE, Hasnoot K, Sutaryo, Veerman AJP, Thijs LG. Inflamatory mediators in dengue virus infection in children: interleukin- 6 and its relation to C- Reactive protein and secretory phospholipase A2. Am J Trop Med Hyg 2001;65:70-5.

11. Nagassar RP, Nagassar RJB, Nathalie M, Karen JRG. Staphylococcus aureus pneumonia and dengue virus co-infection and review of implication of coinfection. BMJ case report 2012. doi:10.1136/bcr.02.2012.5804.

12. Araujo SA, Moreira DR, Nobre V. Fatal Staphylococcal infection following classic dengue fever. Am J Trop Med Hyg 2010;83:679-82. 